\title{
ANALISIS KESEMPATAN KERJA DI PROVINSI SULAWESI UTARA
}

\author{
Muchlis Suratinoyo \\ Oktavianus Porajouw \\ Martha M. Sendow
}

\begin{abstract}
ABSRACT
This study aims to describe the development of employment and analyze changes in the structure of employment by employment and employment status in North Sulawesi Province. This study uses secondary data of Population Census, National Labor Force Survey, and North Sulawesi in Figures 2010 and 2015. Data analysis using simple calculation method, that is data according to employment and job status calculated percentage then displayed in table and graph form to explain about changes of labor structure in North Sulawesi Province. The results showed that employment opportunities according to employment in North Sulawesi Province dominated by three sectors, namely the agricultural sector, service sector, and trade sector. Sectors in the secondary sector are low in providing employment opportunities in North Sulawesi. If employment is simplified into three sectors, namely primary, secondary and tertiary sectors, then the largest employment opportunities are in the tertiary sector (trade, transportation, finance, services), then primary (agriculture), and the lowest in the secondary sector (mining, industry, electricity and buildings). Based on employment status, the highest percentage is to work as a worker/employeelemployee with an increasing tendency. However, when grouped into formal and informal sectors, the highest employment opportunity is in the informal sector. Based on the result of the research, it is concluded that job opportunity of agriculture sector still dominates employment in North Sulawesi. The role of agriculture/primary sector in providing job opportunities decreased; on the contrary the service sector/tertiary role was increasing. Employment opportunities by employment status in North Sulawesi, the highest percentage is employed as laborers/employees/employees. The role of the formal sector in providing employment increases, while the informal sector is declining.
\end{abstract}

\section{Keywords: analyze, employment opportunity, North Sulawesi Province}

\begin{abstract}
ABSTRAK
Penelitian ini bertujuan untuk mendeskrisikan perkembangan ketenagakerjaan dan menganalisis perubahan struktur kesempatan kerja menurut lapangan pekerjaan dan status pekerjaan di Provinsi Sulawesi Utara. Penelitian ini menggunakan data sekunder Sensus Penduduk, Survey Angkatan Kerja Nasional, dan Sulawesi Utara Dalam Angka. Analisis data menggunakan metode perhitungan sederhana, yaitu data menurut lapangan pekerjaan dan status pekerjaan dihitung persentasenya kemudian ditampilkan dalam bentuk tabel dan grafik untuk menjelaskan tentang perubahan-perubahan struktur ketenagakerjaan di Provinsi Sulawesi Utara.Hasil penelitian menunjukkan bahwa kesempatan kerja menurut lapangan pekerjaan di Provinsi Sulawesi Utara di dominasi oleh tiga sektor, yaitu berturut-turut adalah sektor pertanian, sektor jasa-jasa, dan sektor perdagangan. Sektor-sektor pada kelompok sektor sekunder tergolong rendah dalam menyediakan kesempatan kerja di Sulawesi Utara. Apabila lapangan pekerjaan disederhanakan kedalam tiga sektor, yaitu sektor primer, sekunder, dan tersier, maka kesempatan kerja terbesar adalah di sektor tersier (perdagangan, angkutan, keuangan, jasa-jasa), kemudian primer (pertanian), dan terendah di sektor sekunder (pertambangan, industri, listrik dan bangunan). Berdasarkan status pekerjaan, persentase tertinggi adalah bekerja sebagai buruh/karyawan/pegawai dengan kecenderungan yang meningkat. Akan tetapi, bila dikelompokkan kedalam sektor formal dan informal, kesempatan kerja tertinggi adalah di sektor informal. Berdasarkan hasil penelitian disimpulkan bahwa kesempatan kerja sektor pertanian masih mendominasi lapangan pekerjaan di Sulawesi Utara. Peranan sektor pertanian/primer dalam menyediakan kesempatan kerja semakin menurun, sebaliknya sektor jasa/tersier peranannya semakin meningkat. Kesempatan kerja menurut status pekerjaan di Sulawesi Utara, persentase tertinggi adalah bekerja sebagai buruh/karyawan/pegawai. Peranan sektor formal dalam menyediakan kesempatan kerja semakin meningkat, sebaliknya sektor informal semakin menurun.
\end{abstract}

Kata kunci: Analisis, Kesempatan Kerja, Provinsi Sulawesi Utara

\section{PENDAHULUAN}

\section{Latar Belakang}

Pembangunan adalah proses merubah suatu kondisi kearah yang lebih baik dari kondisi sebelumnya. Tujuan akhir setiap pembangunan di suatu negara adalah tercapainya masyarakat yang maju dan sejahtera. Tingkat kesejahteraan masyarakat dapat di capai melalui pembangunan disemua sektor ekonomi secara seimbang. Pembangunan ekonomi yang seimbang akan memberikan kontribusi yang tinggi bagi pembentukan produk domestik bruto dan serapan tenaga kerja 
disemua sektor. Indonesia sebagai negara agraris, kontribusi sektor pertanian dalam pembentukan produk domestik bruto (PDB) dan penyerapan tenaga kerja masih tergolong tinggi.Kontribusi PDB sektor pertanianterhadap PDB nasional pada tahun 2010 sebesar 14,0 persen dan menurun menjadi 12,6 persen pada tahun 2014. Penyerapan tenaga kerja sektor pertanian pada tahun 2010 sebesar 39,5 persen dan menurun menjadi 34,0 persen pada tahun 2014 (BPS, 2016).Kedua indikator tersebut menunjukkan bahwa telah terjadi perubahan dalam struktur ekonomi nasional.Struktur ekonomi yang didominasi sektor pertanian bergeser ke sektor non pertanian seperti industri dan jasa.Perubahan struktur ekonomi ini merupakan dampak dari keberhasilan pembangunan di berbagai bidang dan sektor, termasuk didalamnya pembangunan sumberdaya manusia.

Pembangunan sumberdaya manusia melalui pembangunan di bidang pendidikan telah berhasil meningkatkan kualitas sumberdaya manusia.Dari sisi suplai, tenaga kerja terdidik dan terampil mengalami peningkatan yang cukup signifikan, namun dari sisi permintaan pembangunan sektor-sektor ekonomi non-pertanian belum mampu menyerap tenaga kerja terdidik.Tenaga kerja terdidik pada umumnya memilih bekerja di sektor modern dan enggan untuk bekerja di sektor pertanian/tradisional.Akibatnya, sektor tradisional mengalami kekurangan tenaga kerja di satu pihak dan di pihak lainnya terjadi pengangguran tenaga kerja terdidik dan terampil. Kondisi seperti ini jika tidak segera di atasi akan berdampak pada meningkatnya angka pengangguran dan kemiskinan. Angka pengangguran akan terus meningkat seiring dengan bertambahnya jumlah angkatan kerja sebagai akibat dari pertambahan jumlah penduduk. Angka pengangguran yang tinggi berdampak negatif terhadap kehidupan ekonomi, sosial, budaya, dan politik suatu negara atau wilayah.

Perekonomian provinsi Sulawesi Utara hingga saat ini masih tetap didominasioleh sektor pertanian sebagai sektor basis. Sektor pertanian sebagai sektor basis harus menjadi sektor penggerak utama perekonomian Sulawesi Utara.Sektor pertanian memberikan kontribusi paling tinggi dalam pembentukan Produk Domestik Regional Bruto (PDRB), yaitu sebesar22,08 persen. Sektor-sektor lainnya yang memberikan kontribusi relatif tinggi adalah sektor perdagangan (12,29\%), konstruksi $(11,46 \%)$, transportasi $(9,85 \%)$, dan sektor industri $(9,81 \%)$. Sektor pertanian juga merupakan sektor yang paling banyak menyerap tenaga kerja. Hasil Survey Angkatan Kerja Nasional (Sakernas) yang dilakukan Badan Pusat Statistik Provinsi Sulawesi Utara tahun 2015 menunjukkan bahwa sektor pertanian, kehutanan, perburuan dan perikanan merupakan lapangan usaha yang menyerap tenaga kerja sebanyak 31.93 persen. Lapangan usaha seperti sektor listrik, gas dan air minum, hanya menyerap tenaga kerja sebesar 0,34 persen. Sektor lembaga keuangan, real estate, usaha persewaan dan jasa perusahaan menurun menjadi 11.42 persen, sementara sektor konstruksi mengalami kenaikan sebesar 6.69 persen.Penduduk yang bekerja, umumnya sebagai buruh/karyawan/pekerja tetap yaitu sekitar 43.93 persen. Kualitas sumberdaya manusia yang semakin meningkat di Sulawesi Utara berdampak pada meningkatnya tenaga kerja terdidik.Tenaga kerja terdidik, sebagaimana dijelaskan di atas, cenderung untuk bekerja di sektor formal dan sektor modern dengan tingkat upah yang relatif lebih tinggi dibandingkan upah di sektor pertanian tradisional.Sektor modern, walaupun terus mengalami peningkatan, namun belum mampu menyerap tambahan tenaga kerja.Angka pengangguran terbuka tergolong tinggi dan lebih tinggi dari rata-rata nasional,bahkan cenderung meningkat.Pada tahun 2015, angka pengangguran terbuka provinsi Sulawesi Utara sebesar 9,03 persen, lebih tinggi dari rata-rata nasional yaitu sebesar 6,18 persen, bahkan tertinggi di Indonesia Timur. Angka pengangguran tersebut mengalami kenaikan dibandingkan tahun 2012 sebesar 7,98 persen (BPS, 2016). Kenyataan tersebutlah yang mendorong penulis untuk melakukan penelitian dengan judul: Analisis Kesempatan Kerja di Provinsi Sulawesi Utara.

\section{Rumusan Masalah}

Berdasarkan latar belakang permasalahan yang dikemukan di atas makan masalah utama dalam penelitian ini adalah bagaimana kesempatan kerja berdasarkan lapangan pekerjaan dan status pekerjaan di Provinsi Sulawesi Utara. 


\section{Tujuan Penelitian}

Penelitian ini bertujuan untuk mendeskripsikan perkembangan ketenagakerjaan dan menganalisis perubahan struktur kesempatan kerja berdasarkan lapangan pekerjaan dan status pekerjaan di Provinsi Sulawesi Utara.

\section{Manfaat Penelitian}

Penelitian ini bermanfaat bagi penulis dalam memperdalam pengetahuan ilmiah tentang ketenagakerjaan di Indonesia.Selain itu, penelitian ini juga bermanfaat bagi para pemerhati dibidang ketenagakerjaan sebagai bahan referensi perkuliahan dan penelitian.Penelitian ini juga bermanfaat bagi pemerintah Provinsi Sulawesi Utara dalam menyusun kebijakan dan strategi pembangunan yang dapat mengatasi masalah pengangguran di Sulawesi Utara.

\section{METODOLOGI PENELITIAN}

\section{Tempat dan Waktu Penelitian}

Penelitian ini mengambil lokasi di Provinsi Sulawesi Utara dan dilaksanakan dalam waktu 3 (tiga) bulan yaitu bulan November2016 sampai Januari2017 mulai dari persiapan sampai penulisan laporan penelitian.

\section{Pengumpulan Data}

Penelitian ini menggunakan data sekunder yang dikumpulkan dari hasil Sensus Penduduk 2000 dan 2010. Selain data sensus penduduk, juga menggunakan data Survey Angkatan Kerja Nasional (Sakernas), dan Sulawesi Utara Dalam Angka yang dipublikasikan oleh Badan Pusat Statistik Provinsi Sulawesi Utara. Dokumendokumen laporan dan hasil-hasil penelitian baik yang dipublikasikan maupun tidak dipublikasikan juga digunakan sebagai sumber data.

\section{Jenis Data dan Pengukuran}

Data yang dibutuhkan dalam penelitian ini dan pengukurannya adalah:

1. Jumlah penduduk adalah banyaknya penduduk menurut kelompok umur dan jenis kelamin di Provinsi Sulawesi Utara. Dinyatakan dalam satuan jiwa, tahun 2000-2015. Tenaga kerja adalah banyaknya penduduk dalam usia kerja, yaitu berumur 15 tahun ke atas menurut kelompok umur dan jenis kelamin di Sulawesi
Utara. Dinyatakan dalam satuan orang, tahun 2000-2015.

2. Angkatan kerja adalah banyaknya penduduk berumur 15 tahun ke atas yangselama seminggu yang lalu sebelum pencacahan mempunyai pekerjaan dan ataumempunyai pekerjaan namun sementara tidak bekerja karena cuti, sakit, menunggu panen, atau tidak mempunyai pekerjaan tapi sedang mencari pekerjaan. Dinyatakan dalam satuan orang dari tahun 2000-2015.

3. Bekerja adalah kegiatan ekonomi yang dilakukan seseorang dengan maksud memperoleh atau membantu memperoleh pendapatan atau keuntungan paling sedikit satu jam (tidak terputus) dalam seminggu yang lalu. Kegiatan tersebut termasuk pekerja tidak dibayar, penduduk yang punya pekerjaan tetapi sementara tidak bekerja karena sakit, cuti, menunggu panen, mogok dan sebagainya. Dinyatakan dalam satuan orang, tahun 2000-2015.

4. Kesempatan kerja adalah banyaknya lapangan pekerjaan yang terisi tercermin dari jumlah penduduk yang bekerja (employed). Dinyatakan dalam satuan orang, dari tahun 2000-2010

5. Produk Domestik Regional Bruto (PDRB)seri 2010 Atas Dasar Harga Berlakudan Harga Konstan menurut lapangan pekerjaan tahun 2010-2015.

6. Lapangan pekerjaan adalah bidang kegiatan dari pekerjaan/usaha/perusahaan/kantor tempat seseorang bekerja, yang dikelompokkan kedalam 9 (Sembilan) menurut Klasifikasi Lapangan Usaha Indonesia (KLUI). Lapangan pekerjaan secara sederhana biasanya dikelompokkan menjadi 3 (tiga) sektor, yaitu: (1) sektor primer yaitu sektor pertanian, perkebunan, kehutanan, perburuan, dan perikanan; (2) sektor sekunder terdiri dari sektor pertambangan, industri, listrik, dan konstruksi; dan (3) sektor tersier yang terdiri dari sektor perdagangan, transportasi, keuangan, dan jasa kemasyarakatan.

7. Status pekerjaan menunjuk pada kedudukan seseorang dalam melakukan kegiatan sebagai apa dalam unit usaha, yang biasanya dibagi ke dalam 5 (lima) kelompok menurut (KLUI), yaitu: a). berusaha sendiri tanpa bantuan orang lain; b). berusaha dibantu buruh tidak tetap/ 
tidak dibayar; c). berusaha dengan buruh tetap/dibayar; d). bekerja sebagai buruh/pegawai/karyawan; e). pekerja keluarga. Status pekerjaan juga digunakan sebagai indikator jumlah tenaga kerja yang bekerja di sektor informal dan sektor formal. Sektor informal terdiri dari butir a), b), e); sedangkan sektor formal terdiri dari butir c) dan d).

\section{Analisis Data}

Data kependudukan dan ketenagakerjaan, dan Produk Domestik Regional Bruto (PDRB) sudah disusun dalam tabel dan dipublikasikan oleh Badan Pusat Statistik. Data dalam tabel-tabel tersebut disederhanakan dan dihitung persentasenya untuk dianalisis dengan cara membandingkan menurut kategori, waktu, dan atau wilayah/nasional. Angka pertumbuhan dihitung dengan menggunakan metode sederhana untuk data time series, dan metode geometrik untuk data yang tersedia hanya dua titik waktu/tahun. Rumus yang digunakan adalah:

1) Metode sederhana:

$\mathrm{r} \quad=$ Pertumbuhan

$$
r=\frac{\mathrm{Pt}-\mathrm{Po}}{\mathrm{P} 0} \times 100 \%
$$

$\mathrm{Pt}=$ Jumlah penduduk pada tahun sekarang

Po = Jumlah penduduk pada tahun dasar

Untuk menghitung tingkat pertumbuhan selama periode lima tahun, maka terlebih dahulu menghitung tingkat pertubuhan tiap tahun, kemudian di rata-ratakan, dengan cara sebagai berikut:

2) Metode geometrik:

$$
r=\frac{r 1+r 2+r 3+r 4+r 5}{5}
$$

$$
P t=P o(1+r)^{t}
$$

$\mathrm{Pt}=$ Jumlah penduduk pada tahun sekarang

Po $=$ Jumlah penduduk pada tahun dasar

$\mathrm{r} \quad=$ Pertumbuhan

$\mathrm{t}=$ selisih tahun sekarang dengan tahun dasar

$$
\text { Rumus operasionalnya: } \quad \mathrm{r}=\left(\frac{\log \left(\frac{\mathrm{Pt}}{\mathrm{Po}}\right)}{\mathrm{t}}-1\right) * 100
$$

\section{HASIL PENELITIAN DAN PEMBAHASAN}

\section{Deskripsi Penduduk}

Penduduk merupakan salah satu aspek yang sangat penting dalam pembangunan suatu negara atau daerah, karena penduduk selain sebagai subyek pembangunan maupun sebagai obyek pembangunan.Oleh karena itu, dalam perencanaan pembangunan di Indonesia diisyaratkan bahwa pembangunan harus berpusat pada penduduk (population centered development).Pembangunan yang berpusat pada penduduk memiliki dimensi yang sangat luas, baik dari segi kuantitas maupun segi kualitas.Jumlah penduduk yang besar dan berkualitas merupakan modal pembangunan, tapi sebaliknya jumlah penduduk yang besar dengan kualitas rendah merupakan penghambat pembangunan.Bagian ini memberikan gambaran tentang jumlah dan laju pertumbuhan penduduk serta struktur penduduk menurut umur, jenis kelamin dan tingkat pendidikan di Provinsi Sulawesi Utara.

\section{Jumlah penduduk dan laju pertumbuhan}

Jumlah dan pertumbuhan penduduk saat ini sangat ditentukan oleh perkembangan jumlah penduduk di masa lalu.Perkembangan jumlah penduduk dan laju pertumbuhan penduduk Sulawesi Utara digambarkan berdasarkan hasil sensus penduduk tahun 1990 sampai dengan tahun 2010 serta hasil proyeksi tahun 2015 (Tabel 1).Jumlah penduduk Sulawesi Utara mengalami kenaikan yang cukup tinggi pada periode 20002010 sebesar 270 ribu jiwa atau naik sembilan kali lipat dibandingkan periode 1990-2000 hanya sebesar 30.871 jiwa.Hasil proyeksi tahun 2015 juga menunjukkan kenaikan yang cukup signifikan, yaitu sebesar 142 ribu jiwa selama lima tahun. Kenaikan jumlah penduduk yang tinggi tersebut selain disebabkan oleh angka kelahiran yang masih relatif tinggi dan angka kematian yang terus menurun, kemungkinan juga disebabkan oleh migrasi penduduk yang masuk Sulawesi Utara selama periode 2000-2010.

\begin{tabular}{|c|c|c|}
\hline 1990 & 1.970 .000 & 11,58 \\
\hline 2000 & 2.000 .871 & 1,32 \\
\hline 2010 & 2.270 .596 & 1,28 \\
\hline 2015 & 2.412 .118 & 1,15 \\
\hline
\end{tabular}

Tabel 1. Jumlah Penduduk dan Laju Pertumbuhan Penduduk Tahun 1990-2015

Tabel 1 menunjukan bahwa Peningkatan jumlah penduduk yang cukup tinggi, juga ditunjukkan oleh laju pertumbuhan penduduk yang melambat sejak tahun 2000. Apabila dibandingkan pada periode sensus 1990-2000 
yang menurun cukup tajam yaitu sebesar 0,26 poin, sedangkan periode 2000-2010 hanya turun 0,04 poin, dan 2010-2015 sebesar 0,13 poin. Berdasarkan gambaran perkembangan jumlah penduduk tersebut di atas, maka dapat dikatakan bahwa perkembangan jumlah tenaga kerja di Sulawesi Utara selama periode 20002015 juga menjadi tinggi. Oleh karena, kenaikan jumlah penduduk yang tinggi memberikan kontribusi yang tinggi pada kenaikan jumlah penduduk yang memasuki usia kerja yang disebut sebagai tenaga kerja. Apalagi jika penduduk yang bermigran ke Sulawesi Utara adalah tujuannya untuk kuliah dan bekerja.

\section{Struktur umur penduduk dan jenis kelamin}

Struktur umur dan jenis kelamin penduduk mempunyai pengaruh penting terhadap perubahan-perubahan demografis dan sosial ekonomi. Misalnya, perubahan dari usia bayi dibawah lima tahun ke usia anak, dan seterusnya ke usia remaja dan dewasa. Perubahan-perubahan tersebut mempunyai implikasi kebijakan yang berbeda-beda baik dari aspek biologis maupun aspek sosial dan ekonomi. Dari aspek biologis berkaitan dengan pemenuhan kebutuhan gizi dan kesehatan, aspek sosial berkaitan dengan pendidikan dan ketrampilan, dan dari aspek ekonomi berkaitan dengan lapangan pekerjaan.

\begin{tabular}{cccc} 
Tabel 2. & $\begin{array}{l}\text { Jumlah } \\
\text { Kelompok Umur dan Jenis } \\
\text { Tahun 2015 }\end{array}$ & $\begin{array}{c}\text { Pendumin, } \\
\text { Kelamin }\end{array}$ \\
\hline $\begin{array}{cccc}\text { Golongan } \\
\text { Umur }\end{array}$ & Laki-laki & Perempuan & Jumlah \\
\hline $0-14$ & 25,94 & 25,68 & 25,81 \\
$15-64$ & 68,78 & 67,66 & 68,23 \\
$65+$ & 5,28 & 6,65 & 5,95 \\
\hline \multicolumn{5}{r}{100,00} & 100,00 & 100,00 \\
\hline \multicolumn{2}{l}{ Rasio Ketergantungan } & 34,54 \\
\hline
\end{tabular}

Tabel 2 menunjukan bahwa penduduk Sulawesi Utara tergolong pada kategori penduduk intermediet. Penduduk intermediet ini ditunjukkan oleh proporsi penduduk umur 1564 tahun yang makin besar, diikuti oleh menurunnya penduduk pada kelompok umur kurang dari 15 tahun dan meningkatnya penduduk pada kelompok umur 65 tahun keatas. Berdasarkan jenis kelamin, secara keseluruhan proporsi penduduk laki-laki lebih besar dari proporsi penduduk perempuan. Kecuali pada kelompok umur 65 tahun keatas, proporsi penduduk perempuan lebih besar dari pada penduduk laki-laki. Hal ini juga ditunjukkan oleh rasio jenis kelamin yang hanya sebesar 83, artinya bahwa penduduk lansia perempuan lebih banyak dari lansia laki-laki.

\section{Tingkat pendidikan penduduk}

Pendidikan merupakan salah satu indikator penting untuk mengukur kualitas penduduk sebagai modal pembangunan,yang berimplikasi pada pekerjaan, pendapatan, dan produktivitas pekerja. Pada Tabel 3 digambarkan jumlah dan persentase penduduk Sulawesi Utara berdasarkan tingkat pendidikan sejak tahun 2000 sampai tahun 2015. Persentase penduduk yang tidak/belum tamat sekolah dasar dan tamat sekolah dasar menurun, sebaliknya pada tingkat pendidikan SLTP keatas cenderung meningkat. Peningkatan yang cukup signifikan pada tingkat pendidikan SLTA dan Universitas.

Tabel 3. Persentase Penduduk Menurut Tingkat Pendidikan di Sulawesi Utara 2000-2015

\begin{tabular}{lccc}
\hline \multicolumn{1}{c}{ Tingkat Pendidikan } & 2000 & 2010 & $\left.2015^{*}\right)$ \\
\hline TTSD & 25,9 & 24,5 & 21,06 \\
SD & 32,3 & 25,9 & 23,17 \\
SLTP & 17,9 & 19,3 & 20,18 \\
SLTA & 20,3 & 24,7 & 28,46 \\
Dipl. I/II/III & 1,5 & 1,6 & 1,68 \\
Universitas & 2,1 & 4,0 & 5,45 \\
\hline Jumlah & 100 & 100 & 100 \\
\hline
\end{tabular}

Sumber: BPS; Sensus Penduduk 2000;2010

Tabel 3 menunjukan bahwa persentase tingkat pendidikan penduduk tertinggi adalah SLTA, yakni hampir 30 persen pada tahun 2015.Tingkat pendidikan sekolah dasar dan tidak tamat SD masih tergolong tinggi, yakni 44,2 persen. Kondisi ini disebabkan data tingkat pendidikan termasuk penduduk yang saat ini berada pada kelompok umur 50 tahun ke atas. Penduduk pada kelompok umur ini pada umumnya hanya tamat SD dan tidak sekolah, terutama penduduk yang tinggal di daerah perdesaan dan terpencil. Akan tetapi pada tingkat pendidikan terendah ini, Sulawesi Utara 
berada dibawah rata-rata nasional yaitu sebesar 46,3 persen. Berdasarkan gambaran di atas dapat disimpulkan, bahwa tingkat pendidikan penduduk di Sulawesi Utara semakin meningkat. Hal ini berarti bahwa kualitas sumberdaya manusia Sulawesi Utara semakin meningkat. Tingkat pendidikan penduduk tergolong tinggi dibandingkan dengan rata-rata nasional. Persentase penduduk yang tamat SLTA ke atas sebesar 35,6 persen dibandingkan tingkat nasional sebesar 32,2 persen.

\section{Ketenagakerjaan}

\section{Tenaga kerja}

Tenaga kerja sesuai definisi adalah penduduk dalam usia kerja yang terdiri dari angkatan kerja dan bukan angkjatan kerja. Angkatan kerja adalah penduduk yang sedang bekerja dan yang mencari pekerjaan, sedangkan bukan angkatan kerja adalah penduduk yang melakukan kegiatan lain seperti bersekolah, mengurus rumah tangga dan penerima pendapatan. Gambar 1 menjelaskan perkembangan jumlah tenaga kerja di Sulawesi Utara sejak tahun 2000-2015. Berdasarkan data tersebut, tenaga kerja bertambah sebesar 197.944 orang $(13,72 \%)$ selama 10 tahun pada periode 2000-2010 atau rata-rata bertambah sebesar 19 ribu orang setiap tahun. Kemudian pada periode 2010-2015 bertambah sebesar 153.509 orang $(9,36 \%)$ selama lima tahun atau rata-rata bertambah sebesar 30 ribu orang, lebih tinggi dibandingkan periode sebelumnya (2000-2010).

Gambar 1. Jumlah Tenaga Kerja Sulawesi Utara, 2000-2015

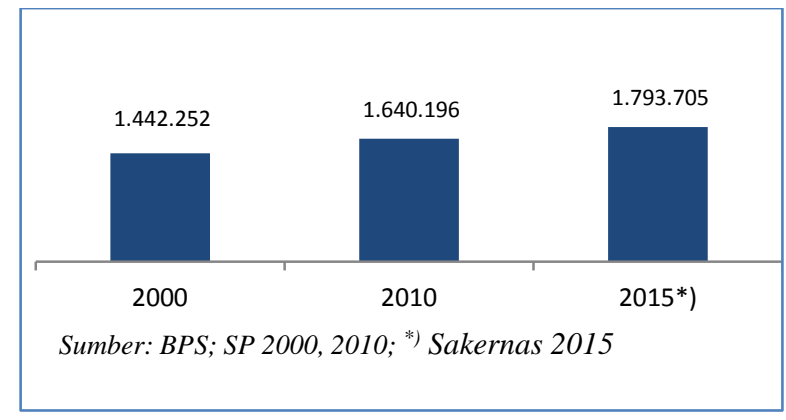

\section{Angkatan kerja}

Angkatan kerja di Sulawesi Utara meningkat seiring dengan peningkatan jumlah tenaga kerja. Gambar 1. memperlihatkan perkembangan jumlah angkatan kerja Sulawesi Utara bertambah sebesar 136.652 orang selama 10 tahun pada periode 2000-2010 naik sebesar 14,61 persen atau rata-rata setiap tahun bertambah hampir 14 ribu orang. Pada periode 2010-2015 cenderung menurun yaitu lebih dari lima ribu orang setiap tahun. Angkatan kerja yang bekerja, secara kuantitas terus meningkat, namun secara relatif cenderung menurun.

Gambar 2. Jumlah angkatan kerja Sulawesi Utara. 2000-2015

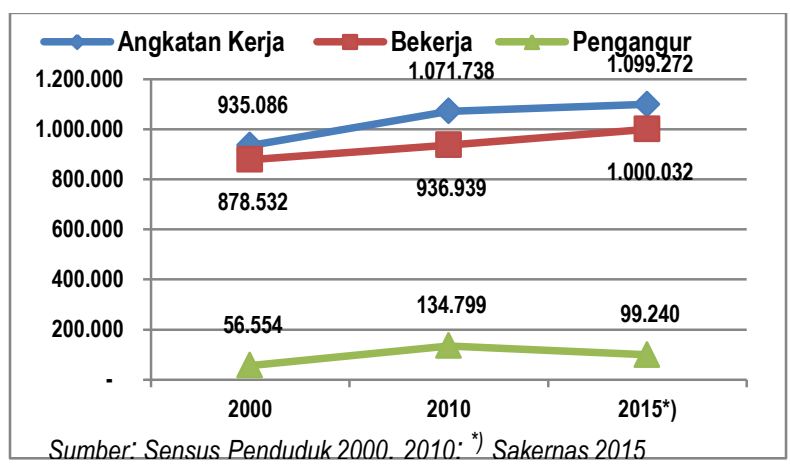

Pada tahun 2000, angkatan kerja yang bekerja sebesar 93,95 persen, tahun 2010 turun menjadi 87,42 perse, kemudian tahun 2015 naik menjadi 90,97 persen tetapi persentasenya lebih rendah dari tahun 2000. Penurunan ini berdampak pada meningkatnya angka pengangguran terbuka dari 6,06 persen tahun 2000 menjadi 9,03 persen tahun 2015. Kondisi ini menggambarkan bahwa pembangunan ekonomi di Sulawesi Utara selama periode tersebut belum dapat mengimbangi tambahan angkatan kerja.

Gambar 3. Persentase Pengangguran menurut tingkat pendidikan di Sulawesi Utara tahun 2015

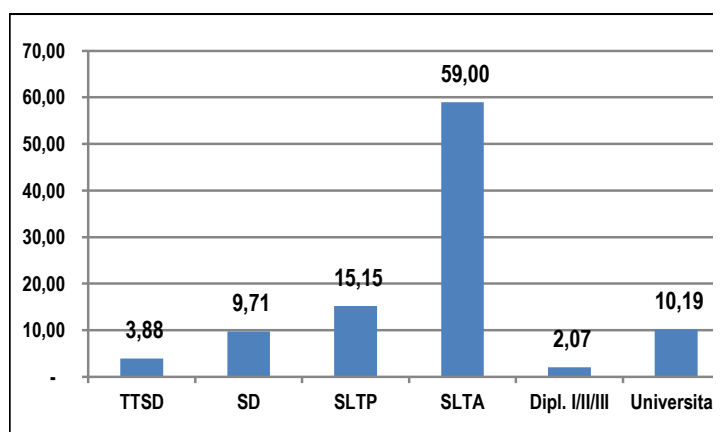

Pengangguran di Sulawesi Utara pada tahun 2015, apabila dilihat berdasarkan tingkat pendidikan, maka pengangguran tertinggi 
adalah pada tingkat pendidikan SLTA yaitu hampir 60 persen dari jumlah penganggur (Gambar 3). Persentase pengangguran yang perlu mendapatkan perhatian juga adalah pada tingkat pendidikan diploma dan universitas. Pengangguran lulusan diploma dan universitas secara relatif mungkin dianggap rendah, tetapi secara kuantitif tergolong besar, yakni sebanyak 12 ribu orang. Jumlah pengangguran yang besar itu perlu mendapat perhatian serius semua pihak, baik pemerintah maupun pihak swasta dan masyarakat.

\section{Kesempatan Kerja}

Tersedianya kesempatan kerja baru atau disebut dengan lapangan kerja adalah untuk mengatasi peningkatan angkatan kerja yang terus bertambah setiap tahun. Penyediaan lapangan kerja menjadi target utama dalam setiap perencanaan pembangunan ekonomi di daerah. Jika tidak, maka angka pengangguran angkatan tenaga terdidik akan terus meningkat yang berdampak pada kehidupan ekonomi dan sosial. Perluasan lapangan kerja hanya dapat dilakukan melalui peningkatan investasi langsung (direct investment) pada sektor-sektor yang bersifat padat karya, seperti konstruksi, infrastruktur maupun industri pengolahan. Perkembangan ekonomi dan kemajuan teknologi makin membutuhkan tenaga kerja yang berkualitas yaitu tenaga kerja terdidik dan terampil untuk mengisi lowongan kerja di sektor modern. Kualitas tenaga kerja yang tersedia seringkali tidak sesuai dengan kualifikasi yang dibutuhkan. Pada kualifikasi tertentu sering terjadi kelebihan persediaan sementara pada kualifikasi yang lain sering tidak tersedia secara memadai. Akibatnya tenaga kerja yang tidak tertampung berusaha untuk bekerja walaupun tidak sesuai kualifikasi, berusaha sendiri atau sebagai pekerja keluarga. Pada bagian ini menguraikan kesempatan kerja menurut lapangan usaha/sektor pekerjaan dan status pekerjaan.

\section{Lapangan pekerjaan utama}

Proses pembangunan ekonomi dalam jangka panjang telah menyebabkan terjadinya perubahan pada struktur ekonomi dari sektor pertanian ke sektor industri dan jasa. Sektor pertanian diidentikkan dengan sektor primer, sektor industri sebagai sektor sekunder dan sektor jasa sebagai sektor tersier. Sektor-sektor tersebut berdasarkan konsep Badan Pusat Statistik (BPS) disebut dengan lapangan pekerjaan utama. Lapangan pekerjaan utama sesuai data yang dipublikasikan oleh BPS berdasarkan hasil sensus dan survei adalah penduduk berumur 15 tahun keatas yang bekerja selama seminggu yang lalu pada saat sensus atau survei. Menurut Rusli (1995) jumlah penduduk yang bekerja mencerminkan jumlah kesempatan kerja, bahwa kesempatan kerja bukanlah lapangan pekerjaan yang masih terbuka. Kesempatan kerja berdasarkan lapangan pekerjaan utama/sektor di Provinsi Sulawesi Utara tahun 2010-2015 dijelaskan pada Gambar 4.

Gambar 4. Persentase kesempatan kerja menurut sektor di Sulawesi Utara, 2010 dan 2015

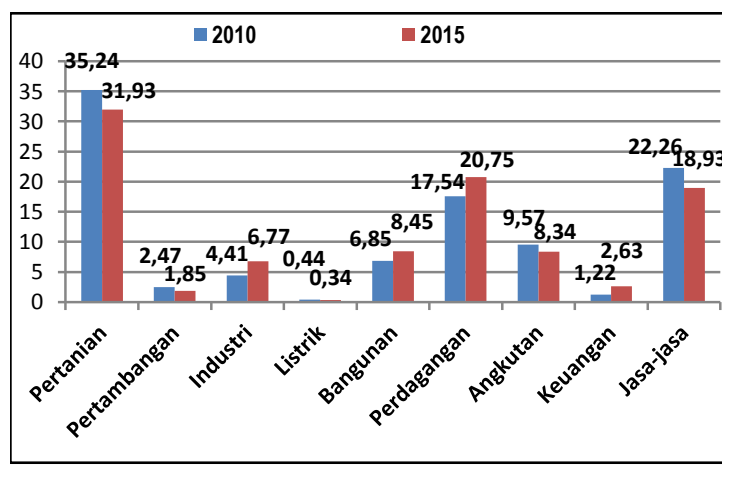

Sumber: BPS; Sensus Penduduk 2010 dan Sakernas, 2015

Secara keseluruhan, kesempatan kerja masih didominasi oleh sektor pertanian, sektor jasa-jasa, dan sektor perdagangan. Namun sektor pertanian dan jasa cenderung menurun, dan hanya sektor perdagangan yang cenderung meningkat. Sektor lainnya yang memberikan kontribusi kesempatan kerja yang cukup besar dan cenderung meningkat adalah sektor bangunan dan industri pengolahan. Sektor industri pengolahan selama periode lima tahun menyerap hampir 30 ribu tenaga kerja, dan sektor bangunan lebih dari 20 ribu tenaga kerja (Lampiran Tabel 4). Demikian pula sektor keuangan, walaupun relatif rendah tetapi berhasil menyerap sekitar 15 ribu tenaga kerja selama lima tahun. Sektor angkutan juga relatif tinggi kontribusinya dalam menyerap tenaga kerja namun sektor ini cenderung menurun. Struktur kesempatan kerja di Sulawesi Utara telah mengalami pergeseran yang cukup berarti. Perubahan ini semakin jelas terlihat apabila sektor ekonomi disederhanakan kedalam tiga sektor utama, yaitu sektor primer, sekunder dan tersier. Gambar 4.5 menunjukkan perubahan pola strukktur kesempatan kerja di Sulawesi 
Utara. Peran sektor primer yang sangat besar dalam menyerap tenaga kerja sejak awal pembangunan, sekarang ini telah bergeser ke sektor tersier.

Gambar 5. Perubahan struktur kesempatan kerja berdasarkan tiga sektor utama

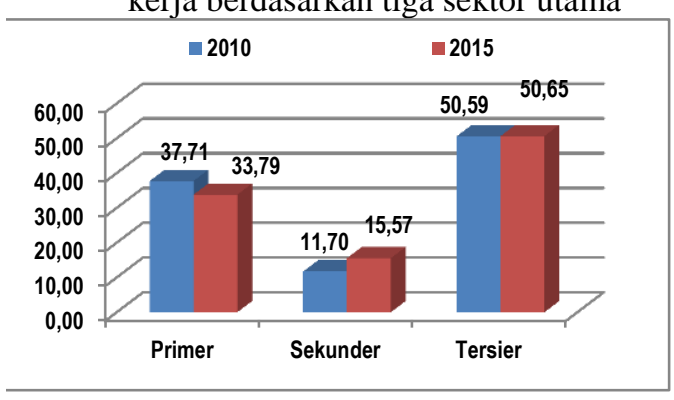

Sumber: BPS; Sensus penduduk 2010; Sakernas 2015

Perubahan pola struktur kesempatan kerja menurut sektor juga dapat dilihat berdasarkan jenis kelamin. Sektor tersier lebih didominasi oleh tenaga kerja perempuan, sedangkan sektor primer dan sekunder didominasi oleh tenaga kerja lakilaki. Tenaga kerja laki-laki, selain sektor pertanian, sektor lainnya yang cukup dominan adalah sektor bangunan, transportasi, tetapi juga jasa dan perdagangan.Sedangkan tenaga kerja perempuan selain sektor perdagangan, sektor jasajasa juga paling dominan. Berdasarkan uaraian di atas, dapat disimpulkan bahwa dimasa mendatang, kebijakan dan strategi pembangunan di Sulawesi Utara, lebih diarahkan pada sektor tersier. Hal ini tidak berarti mengabaikan sektor sekunder dan sektor primer, tetapi kesempatan kerja sektor perdagangan dan jasa adalah sektor yang paling banyak menyerap tenaga kerja, baik tenaga kerja laki-laki maupun perempuan. Oleh karena itu kebijakan pembangunan ekonomi lebih di tingkatkan di sektor-sektor tersebut, agar tercipta lapangan kerja baru untuk menyerap kelebihan persediaan angkatan kerja.

\section{Status pekerjaan}

Kesempatan kerja menurut status pekerjaan di Sulawesi Utara mengalami perubahan komposisi yang cukup signifikan selama 15 tahun dari tahun 2000 sampai 2015. Perubahan komposisi kesempatan kerja menurut status pekerjaan digambarkan pada Tabel 4.4. Pada tahun 2000 dan 2010 persentase tertinggi pada status pekerjaan berusaha sendiri, sedangkan pada tahun 2015 persentase tertinggi pada status pekerjaan buruh/karyawan/pegawai. Status pekerjaan berusaha sendiri tanpa buruh, berusaha dibantu buruh tidak tetap, dan pekerja keluarga cenderung menurun. Berusaha dibantu buruh tetap, buruh/karyawan/pegawai, dan pekerja bebas cenderung meningkat. Perubahan-perubahaan komposisi status pekerjaan tersebut sebagai akibat dari perubahan struktur ekonomi yang berdampak pada perubahan struktur kesempatan kerja. Peningkatan yang sangat berarti pada status pekerjaan berusaha sendiri dibantu pekerja tetap, dan pekerja bebas menunjukkan bahwa peluang usaha semakin terbuka di Sulawesi Utara.

Tabel 4. Persentase kesempatan kerja menurut status pekerjaan utama di Sulawesi Utara, 20002010

\begin{tabular}{lccc}
\hline \multicolumn{1}{c}{ Status Pekerjaan Utama } & 2000 & 2010 & $2015^{*}$ \\
\hline $\begin{array}{l}\text { Berusaha sendiri } \\
\begin{array}{l}\text { Berusaha dibantu buruh } \\
\text { tetap/tidak dibayar }\end{array}\end{array}$ & 40,4 & 33,78 & 24,53 \\
$\begin{array}{l}\text { Berusaha dibantu buruh } \\
\text { tetap/dibayar }\end{array}$ & 11,2 & 6,60 & 9,92 \\
$\begin{array}{l}\text { Buruh/Karyawan/Pegawai } \\
\text { Pekerja bebas }\end{array}$ & 1,2 & 4,46 & 4,04 \\
$\begin{array}{l}\text { Pekerja keluarga/tak } \\
\text { dibayar }\end{array}$ & 0,30 & 14,34 & 16,36 \\
\hline Jumlah & 16,7 & 7,90 & 8,74 \\
\hline
\end{tabular}

Sumber: BPS; Sensus penduduk 2000,2010

Tabel 4 menunjukan perubahanperubahan struktur kesempatan kerja sebagaimana digambarkan di atas semakin jelas terlihat jika status pekerjaan dikelompokkan kedalam sektor formal dan sektor informal. Status pekerjaan berusaha dibantu buruh tetap/dibayar dan status pekerjaanburuh/karyawan/pegawai dikelompokkan kedalam sektor formal. Status pekerjaan berusaha sendiri, berusaha dibantu buruh tidak dibayar, pekerja bebas dan pekerja keluarga dikelompokkan kedalam sektor informal. Berdasarkan pengelompokkan tersebut, perkembangan sektor formal dan sektor informal di Provinsi Sulawesi Utara selama periode tahun 2000 hingga tahun 2015 dapat dilihat pada Gambar 6. Gambar 6 menunjukkan bahwa sektor informal masih memegang peran penting dalam menyiapkan lapangan pekerjaan di Sulawesi Utara dibandingkan sektor formal. Persentase kesempatan kerja di sektor informal pada tahun 2015 lebih tinggi 19 persen dibandingkan sektor formal. Akan tetapi, sektor formal menunjukkan persentase yang meningkat, sebaliknya sektor informal persentasenya semakin menurun. Penyerapan kesempatan kerja di sektor formal sangat besar selama periode 2000-2010 dan 2010- 
2015, yaitu masing-masing sebesar 57 ribu dan 68 ribu tenaga kerja. Sedangkan sektor informal pada periode 2000-2010 sempat mengalami penurunan lebih dari 30 ribu tenaga kerja. Pada periode 2010-2015 sektor informal sebanyak 32 ribu tenaga kerja. Sektor informal di Sulawesi Utara mulai berkembang positif pada periode 20102015.

Gambar 6. Persentase kesempatan kerja menurut sektor formal dan informal, 2000-2015

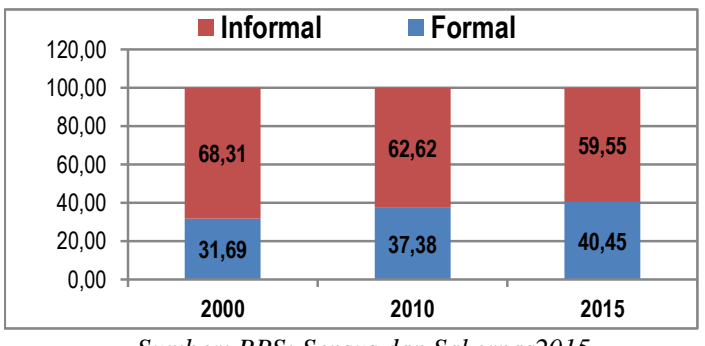

Sumber: BPS; Sensus dan Sakernas2015

Berdasarkan jenis kelamin, tenaga kerja laki-laki lebih banyak bekerja di sektor informal, sebaliknya tenaga kerja perempuan lebih banyak bekerja di sektor formal (Gambar 7). Persentase tertinggi laki-laki bekerja di sektor informal karena sebagian besar penduduk di Sulawesi Utara berprofesi sebagai petani. Sebagaimana ditunjukkan pada bagian sebelunnya bahwa persentase terbesar $(31 \%)$ kesempatan kerja di sektor pertanian (Gambar 4). Sebaliknya, tenaga kerja perempuan dengan tingkat pendidikan yang semakin tinggi memilih bekerja di sektor modern dan formal.

Gambar 7. Persentase kesempatan kerja menurut status pekerjaan dan jenis kelamin, 2015

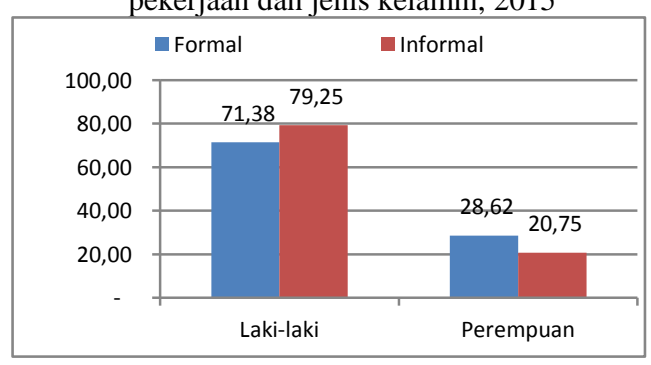

Sumber: BPS; Sakernas 2015

Gambaran tentang kesempatan kerja baik menurut sektor/lapangan pekerjaan maupun status pekerjaan, mengindikasikan bahwa kebijakan dan strategi pembangunan daerah di Sulawesi Utara harus diarahkan pada lapangan pekerjaan yang dapat menciptakan lapangan pekerjaan baru. Percepatan pembangunan di sektor tersier dan sekunder harus mendapat perhatian yang serius oleh pemerintah provinsi dan kabupaten/kota. Sektor informal adalah sektor yang menyerap tenaga kerja terbesar di Sulawesi Utara. Oleh karena itu, kegiatan usaha mikro, kecil dan menengah terus ditingkatkan dan dikembangkan. Pada bagian berikut ini digambarkan tentang kondisi perekonomian di Sulawesi Utara.

\section{Gambaran Perekonomian Sulawesi Utara}

Gambaran perekonomian Sulawesi Utara dalam tulisan ini hanya di dasarkan pada Produk Domestik Regional Bruto (PDRB) seri 2010 berdasarkan harga berlaku dan harga konstan. PDRB harga berlaku digunakan untuk menjelaskan kondisi real perekonomian, sedangkan PDRB harga konstan digunakan untuk menjelaskan perkembangan perekonomi Sulawesi Utara. PDRB seri 2010 berbeda dengan PDRB seri 2000, baik penggunaan harga konstan maupun rincian lapangan pekerjaan. Pada PDRB seri 2010, menggunakan harga konstan tahun 2010 dengan 17 kategori lapangan pekerjaan, konsep sebelumnya sembilan kategori. Tabel 5 memberikan gambaran kondisi perekonomian Sulawesi Utara berdasarkan PDRB seri 2010 dan Tabel 6 dirinci menjadi tiga sektor utama agar dapat di bandingkan dengan kesempatan kerja. Struktur perekonomian Sulawesi Utara sampai tahun 2015 masih didominasi oleh lapangan usaha kategori pertanian, kehutanan, dan perikanan; kategori perdagangan besar dan eceran, reparasi mobil dan sepeda motor; dan kategori konstruksi. Lapangan usaha ketiga kategori tersebut memberikan kontribusi sebesar 45,6 persen terhadap PDRB total Provinsi Sulawesi Utara. Tabel 6 menunjukan bahwa kategori transportasi dan pergudangan, kategori industri pengolahan dan kategori administrasi pemerintahan, pertahanan dan jaminan sosial juga merupakan penyumbang kedua terbesar dalam perekonomian Sulawesi Utara. PDRB total Sulawesi Utara hampir 30 persen merupakan sumbangan dari ketiga kategori tersebut. Selain itu, pertumbuhan ketiga kategori itu juga relatif tinggi. Kategorikategori yang walaupun kontribusinya tergolong rendah, tetapi pertumbuhannya cukup tinggi adalah kategori informasi dan komunikasi, kategori real estate, jasa kesehatan dan kegiatan sosial, kategori pertambangan dan penggalian, dan kategori jasa keuangan dan asuransi. Sumbangan kelima kategori itu terhadap PDRB total hanya 19 
persen tetapi pertumbuhannya ada pada kisaran 78 persen per tahun.Kondisi perekonomian Sulawesi Utara sebagaimana digambarkan di atas mengindikasikan bahwa kinerja pembangunan ekonomi yang dilaksanakan pemerintah daerah baik di level provinsi maupun di level kabupaten dan kota menunjukkan hasil yang positif. Apakah capaian hasil pembangunan tersebut telah memberikan kontribusi yang positif bagi penciptaan lapangan pekerjaan di Sulawesi Utara? Untuk membandingkan capaian hasil pembangunan dengan penyerapan tenaga kerja, maka 17 kategori lapangan usaha dikelompokkkan kedalam tiga sektor utama seperti ditunjukkan pada Tabel 6. Tabel 6 menunjukkan bahwa lebih dari 50 persen PDRB total Sulawesi Utara tahun 2015 berasal dari sektor ini. Penyumbang terbesar pada kategori ini adalah lapangan usaha perdagangan besar dan eceran, reparasi mobil dan sepeda motor, lapangan usaha transportasi dan pergudangan, dan administrasi pemerintahan, pertahanan dan jaminan sosial. Sektor sekunder, walaupun terendah dalam memberikan kontribusi terhadap PDRB total, tetapi sektor ini bertumbuh cukup tinggi. Kategori konstruksi dan kategori industri pengolahan terutama industri makanan dan minuman menjadi penentu di sektor sekunder. Sektor primer yang merupakan penyumbang kedua terbesar terhadap PDRB total Sulawesi Utara didominasi oleh kategori perikanan, perkebunan tahunan, tanaman pangan, dan peternakan. Gambar 8 dan Gambar 9 adalah perbandingan antara persentase PDRB dan persentase kesempatan kerja berdasarkan tiga sektor utama di Sulawesi Utara tahun 2010 dan tahun 2015. Kedua gambar tersebut menunjukkan pola yang sama membentuk seperti huruf $\mathrm{V}$. Artinya, semakin tinggi kontribusi PDRB sektor terhadap PDRB total, maka semakin tinggi pula kesempatan kerja di sektor tersebut

Gambar 8 Persentase PDRB menurut sektor 2010 dan 2015

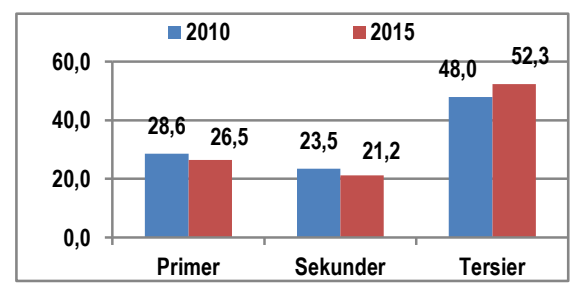

Sumber: BPS; Sulawesi Utara Dalam Angka 2016

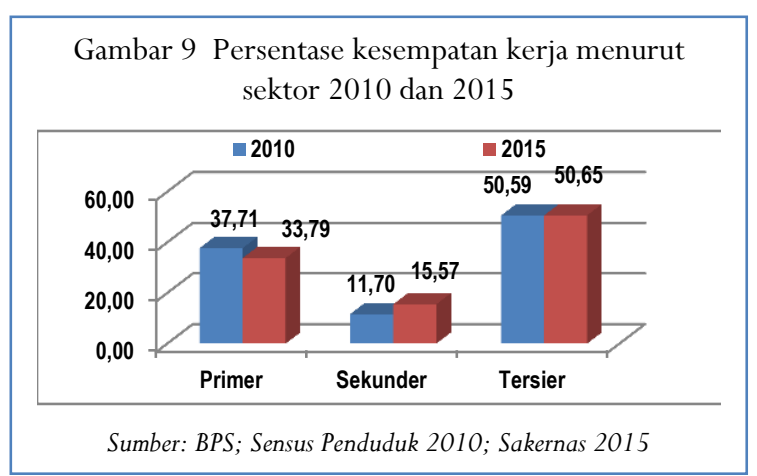

Kontribusi PDRB sektor tersier adalah yang tertinggi terhadap PDRB total dan kesempatan kerja di sektor ini adalah yang tertinggi di Sulawesi Utara. Sebaliknya kontribusi PDRB sektor sekunder adalah yang terendah terhadap PDRB total dan kesempatan kerja di sektor ini juga paling rendah di Sulawesi Utara. Dalam perkataan lain, semakin tinggi PDRB sektor semakin tinggi pula kesempatan kerja disektor yang bersangkutan. Berdasarkan gambaran tersebut di atas, maka untuk meningkatkan kesempatan kerja di Sulawesi Utara, maka output disetiap kategori lapangan usaha harus ditingkatkan. Peningkatan output hanya dapat dilakukan melalui peningkatan produktivitas dan perluasan usaha. Modal usaha sangat dibutuhkan untuk peningkatan dan pengembangan usaha. Modal investasi di sektor-sektor produktif diperbesar untuk menciptakan lapangan pekerjaan baru. Kategori lapangan usaha di sektor tersier masih memiliki peluang untuk ditingkatkan dan dikembangkan, seperti perdagangan, transporasi dan pergudangan, dan jasa-jasa lainnya. Disektor sekunder walaupun kontribusi PDRB menurun, tetapi kesempatan kerja terjadi peningkatan. Oleh karena itu sektor sekunder perlu ditingkatkan dan dikembangkan terus, terutama industri pengolahan makanan dan minuman, dan konstruksi. Sektor primer walaupun kontribusi PDRB sektor dan kesempatan kerja cenderung turun, tetapi sektor ini merupakan sektor yang menyediakan kesempatan kerja cukup besar. Selain itu, sektor ini merupakan sektor basis sebagai penyedia bahan baku industri pengolahan. Oleh karena itu sektor ini harus dikembangkan terus dan dimantapkan untuk mendorong usaha di industri pengolahan. 
Tabel 5 Produk Domestik Regional Bruto ADHB 2010 di Sulawesi Utara (milyar rupiah)

\begin{tabular}{|c|c|c|c|c|c|c|}
\hline \multirow{2}{*}{ Kategori } & \multirow{2}{*}{ Uraian } & \multicolumn{2}{|c|}{2010} & \multicolumn{2}{|c|}{2015} & \multirow{2}{*}{$\begin{array}{c}\text { Pertumbuhan } \\
\%\end{array}$} \\
\hline & & Jumlah & $\%$ & Jumlah & $\%$ & \\
\hline A & $\begin{array}{l}\text { Pertanian, Kehutanan, dan } \\
\text { Perikanan }\end{array}$ & $12,281.01$ & 23.74 & $\begin{array}{l}19,858 . \\
9\end{array}$ & 21.76 & 3.65 \\
\hline B & $\begin{array}{l}\text { Pertambangan dan } \\
\text { Penggalian }\end{array}$ & $2,483.77$ & 4.80 & $4,325.9$ & 4.74 & 7.10 \\
\hline $\mathrm{C}$ & Industri Pengolahan & $5,711.85$ & 11.04 & $8,623.1$ & 9.45 & 5.12 \\
\hline $\mathrm{D}$ & $\begin{array}{l}\text { Pengadaan Listrik dan Gas } \\
\text { Pengadaan Air, }\end{array}$ & 45.21 & 0.09 & 70.9 & 0.08 & 10.47 \\
\hline $\mathrm{E}$ & $\begin{array}{l}\text { Pengelolaan Sampah, } \\
\text { Limbah dan Daur Ulang }\end{array}$ & 75.08 & 0.15 & 120.7 & 0.13 & 5.29 \\
\hline $\mathrm{F}$ & $\begin{array}{l}\text { Konstruksi } \\
\text { Perdagangan Besar dan }\end{array}$ & $6,296.24$ & 12.17 & $10,522.9$ & 11.53 & 7.88 \\
\hline G & $\begin{array}{l}\text { Eceran; Reparasi Mobil } \\
\text { dan Sepeda Motor }\end{array}$ & $6,227.52$ & 12.04 & $11,276.3$ & 12.35 & 7.76 \\
\hline $\mathrm{H}$ & $\begin{array}{l}\text { Transportasi dan } \\
\text { Pergudangan }\end{array}$ & $4,173.61$ & 8.07 & $9,687.9$ & 10.61 & 7.51 \\
\hline I & $\begin{array}{l}\text { Penyediaan Akomodasi } \\
\text { dan Makan Minum }\end{array}$ & $1,034.09$ & 2.00 & $1,961.6$ & 2.15 & 8.39 \\
\hline $\mathrm{J}$ & Informasi dan Komunikasi & $2,127.93$ & 4.11 & $3,489.9$ & 3.82 & 8.59 \\
\hline K & $\begin{array}{l}\text { Jasa Keuangan dan } \\
\text { Asuransi }\end{array}$ & $1,800.41$ & 3.48 & $3,250.8$ & 3.56 & 6.89 \\
\hline $\mathrm{L}$ & Real Estate & $1,791.27$ & 3.46 & $3,195.7$ & 3.50 & 7.75 \\
\hline $\mathrm{M}, \mathrm{N}$ & $\begin{array}{l}\text { Jasa Perusahaan } \\
\text { Administrasi }\end{array}$ & 38.97 & 0.08 & 78.2 & 0.09 & 8.17 \\
\hline $\mathrm{O}$ & $\begin{array}{l}\text { Pemerintahan, Pertahanan } \\
\text { dan Jaminan Sosial Wajib }\end{array}$ & $3,661.52$ & 7.08 & $7,664.9$ & 8.40 & 6.72 \\
\hline $\mathrm{P}$ & Jasa Pendidikan & $1,329.15$ & 2.57 & $2,613.0$ & 2.86 & 5.87 \\
\hline Q & $\begin{array}{l}\text { Jasa Kesehatan dan } \\
\text { Kegiatan Sosial }\end{array}$ & $1,859.99$ & 3.60 & $3,165.5$ & 3.47 & 7.59 \\
\hline $\mathrm{R}, \mathrm{S}, \mathrm{T}, \mathrm{U}$ & Jasa lainnya & 783.70 & 1.52 & $1,369.1$ & 1.50 & 7.17 \\
\hline Produk & Domestik Regional Bruto & $51,721.3$ & 100.00 & $91,275.3$ & 100.00 & 6.37 \\
\hline
\end{tabular}

Sumber: BPS; Sulawesi Utara Dalam Angka 2015

Tabel 6. Produk Domestik Regional Bruto ADHB 2010 Sulawesi Utara (dalam milyar rupiah)

\begin{tabular}{cccccc}
\hline Sektor & 2010 & $\%$ & 2015 & $\%$ & $\mathrm{R}$ \\
Primer & $14,764.78$ & 28.55 & $24,184.83$ & 26.50 & 4.25 \\
Sekunder & $12,128.39$ & 23.45 & $19,337.66$ & 21.19 & 6.60 \\
Tersier & $24,828.17$ & 48.00 & $47,752.80$ & 52.32 & 7.46 \\
Jumlah & $51,721.33$ & 100.00 & $91,275.29$ & 100.00 & 6.37 \\
\hline
\end{tabular}

Sumber: BPS; Sulawesi Utara Dalam Angka 2015 


\section{KESIMPULAN DAN SARAN}

\section{Kesimpulan}

Kesempatan kerja pada lapangan pekerjaan/sektor primer masih relatif tinggi namun cenderung menurun. Kesempatan kerja pada lapangan usaha industri pengolahan dan lapangan usaha bangunan/konstruksi walaupun rendah tetapi cenderung meningkat. Kesempatan kerja pada lapangan usaha perdagangan besar dan eceran, reparasi mobil dan sepeda motor, dan lapangan usaha keuangan cenderung meningkat. Kesempatan kerja pada lapangan usaha angkutan dan jasajasa cenderung menurun. Sektor tersier adalah sektor penyumbang terbesar pada PDRB total dan sektor yang memberikan kesempatan kerja terbesar di Sulawesi Utara. Status pekerjaan berusaha sendiri, berusaha dibantu buruh tidak dibayar, pekerja keluarga (sektor informal) di Sulawesi Utara cenderung menurun, sebaliknya status pekerjaan buruh/karyawan/pegawai dan berusaha dibantu buruh tetap (sektor formal) cenderung meningkat. Perubahan struktur kesempatan kerja mulai begeser dari sektor informal ke sektor formal.

\section{Saran}

Kesempatan kerja pada lapangan usaha pertanian walaupun terus menurun, namun lapangan usaha ini tetap terus ditingkatkan dan di mantapkan karena Produk Domestik Regional Bruto Sulawesi Utara terbesar sumbangan dari sektor ini dan terus mengalami peningkatan. Sektor ini juga merupakan penyedia bahan baku bagi industri pengolahan yang terus mengalami peningkatan di Sulawesi Utara. Kebijakan dan strategi pembangunan bagi pengembangan usaha mikro kecil dan menengah perlu mendapatkan perhatian yang serius oleh semua pihak karena sektor ini juga merupakan penyumbang kesempatan kerja yang cukup besar. Perlu adanya kebijakan yang mempermudah para investor dalam negeri dan luar negeri untuk menginvestasikan modalnya di Sulawesi Utara.

\section{DAFTAR PUSTAKA}

Badan Pusat Statistik Povinsi Sulawesi Utara, 2015, Keadaan Ketenagakerjaan Provinsi Sulawesi Utara, Katalog BPS: 2303004.71, Manado

Badan Pusat Statistik,2016; http://www.bps.go. id/linkTabelStatis/view/id/diakses23 Agustus 2016

Bellante, D. dan M. Janson 2006.Ekonomi Ketenagakerjaan, Lembanga Penerbit Fakultas Ekonomi Universitas Indonesia, Jakarta

Dwiyanto, A., Faturohman, M. Malo, dan I. Abdulah (1996), Penduduk dan Pembangunan, Pusat Penelitian Kependudukan UGM, Yogyakarta.

Kuncoro, M. 2010,Dasar-Dasar Ekonomika Pembangunan, Yogyakarta: UPP STIM YKPN

Rusli S., 1995. Pengantar Ilmu Kependudukan, LP3ES, Jakarta.

Subri, M., 2002, Ekonomi Sumberdaya Manusia, PT RajaGrafindo Persada, Jakarta

Sukirno, S., 2005, Mikroekonomi Teori Pengantar, PT RajaGrafindo Persada, Jakarta

2011.Ekonomi Pembangunan:
Proses, Masalah, dan

Sumarsono, S., 2009, Teori dan Kebijakan Publik Ekonomi Sumberdaya Manusia, Penerbit Graha Imu, Jakarta.

Suroto.1992. Strategi Pembangunan danPerencanaan Kesempatan Kerja. Gajah Mada University Press, Yogyakarta.

Swasono, Y dan E. Sulistyaningsih, 1987, Metode Perencanaan Tenaga Kerja; Tingkat Nasional, Regional, dan Perusahaan, BPFE-Yogyakarta

Undang Undang No.13 Tahun 2000 tentang Ketenagakerjaan di Indonesia 